\title{
THEORETICAL AND METHODOLOGICAL ASPECTS \\ OF THE PREVENTION OF DEVIANT BEHAVIOR \\ IN YOUNGER ADOLESCENTS BY MEANS OF PHYSICAL EXERCISES
}

\author{
Vadym Kharkivskyi \\ Postgraduate Student, Bohdan Khmelnytsky National University of Cherkasy, Ukraine \\ e-mail: dezert1993@ukr.net, orcid.org/0000-0002-4648-3269
}

\section{Andrii Artyushenko}

Doctor of Pedagogical Sciences, Professor at the Department of Sports Disciplines, Bohdan Khmelnytsky National University of Cherkasy, Ukraine e-mail: kudo-cherkasy@ukr.net, orcid.org/0000-0002-3139-3631

\begin{abstract}
Summary
This article substantiates physical culture as a means of preventing deviant behavior in adolescence. It has been proven that focusing on primary prevention allows for the correct formation of the personality, and allows for effective prevention of deviant behavior. For the prevention of deviant behavior, it is necessary to carry out the influence of strengthening mental health, personal development, social and moral improvement, as well as teaching correct behavioral attitudes. The general structure of the components, criteria and indicators of the normative behavior of younger adolescents is determined, on the basis of which deviant and socially acceptable behavior can be distinguished. In the structure of normative behavior, cognitive, emotional-value and activity-behavioral components are identified, in each of which criteria and indicators for assessing the levels of normative behavior of younger adolescents are determined, and types of normative behavior are determined. This structure allows diagnostics and control of preventive activities by means of physical culture.
\end{abstract}

Keywords: deviant behavior, adolescents, younger adolescents, prevention, physical culture, criteria and indicators.

DOI: https://doi.org/10.23856/4406

\section{Introduction}

The solution to the problem of preventing deviant behavior is posed at the national level and is defined in a number of state documents: the Law of Ukraine "On Education", "On Child Protection", "On Social Work with Families, Children and Youth", the concept of preventive education of children and youth in the education system. In addition, in other comprehensive programs "Physical education - the health of the nation", the Concept of physical education in the education system of Ukraine, which understands the education of a healthy person as a physical, mental and social person. Given that behavior is an external and internal response to the satisfaction of their biological, psychological and social needs, and therefore sometimes there is inappropriate action and behavior in the social environment. When performing actions that do not meet the expectations of social, moral, legal and behavioral norms, such a phenomenon appears as deviant behavior. This phenomenon should serve as a set of actions, which includes the formation of a full-fledged personality, with the existing ones not deformed by motives, needs, views and value orientations. The process of physical education has effective means and methods to address this issue. 


\section{Approach to the research problem}

Deviant behavior of minors is one of the problems facing modern society. The solution of this problem at different stages of ontogenesis is devoted to a number of domestic and foreign pedagogical (A. Samoilov, A. Tovkanets, M. Mykytenko, L. Kanishevska, I. Taranenko), social and psychological (S. Revenko, V. Martyniuk, S. Dubinin) studies that play an important role in the prevention of various deviant manifestations are assigned in school, student and out-ofschool education of young people.

In modern theoretical and experimental works in the correction, rehabilitation and education of deviant behavior in adolescents, special attention is focused on the process of physical education and the means of physical culture and sports. In Ukrainian works: a personality-oriented approach (Taranenko, 2017). In Russian scientific works: a differentiated approach to the correction of psychological states (Maksimihina, 2006), physical culture and health-improving activity (Minnegaliev, 2004), physical culture and sports activity of an applied orientation (Tyulkevich, 2004), social and pedagogical health technologies (Zhukov, 2005), pedagogical correction (Novichkova, 2009), education through play and competitive activity (Gerasimova, 2009). Foreign scientific works in the process of physical education: improving social and civic competence students (Martinez, 2015) and others. In these scientific works, mainly the influence is carried out on the correction and rehabilitation of deviant adolescents, but the analysis of the preventive effect as a means of preventing negative behavioral manifestations is insufficiently carried out.

Various kinds of scientific works within the framework of the process of physical education, influencing the formation of basic personality attitudes, such as the will and volitional regulation of A. Artyushenko, I. Dudnyk, the motives and motivation of D. Nechyporenko, personal development of L. Nechyporenko, the moral qualities of B. Shyian and which affect the education of healthy behavior and the formation of positive motivations, moral and volitional attitudes and value orientations, for adolescence is important enough to prevent deviant behavior.

Thus, the upbringing of a socially active, physically healthy person with positive moral, ethical qualities and rules of behavior is an important problem, which leads to a large amount of research on the focus on adolescent behavior. Therefore, the prevention of deviant behavior and its various manifestations is very important in modern society, especially in the school environment, in which young people are formed.

The purpose of the article is to scientifically substantiate physical culture as a means of preventing deviant behavior and to determine the general structure of components, criteria and indicators of normative behavior. According to which it is possible to determine the levels of manifestation of socially normative behavior and highlight socially acceptable and deviant behavior. According to the purpose, the research tasks are defined: 1 . To study the state of the problem of deviant behavior in younger adolescents in pedagogical theory and practice, to determine the role of physical culture in the prevention of deviant behavior in younger adolescents. 2. Define and characterize the components, criteria and indicators of normative behavior and its level.

\section{Materials and methods}

To solve the problems of complex cognition of the subject of research, theoretical methods were used (analysis, comparison, classification and generalization of scientific provisions of psychological and pedagogical literature). 


\section{Substantiation of physical culture in the prevention of deviant behavior}

Adolescence is the most critical period as it is characterized by rapid physical, cognitive and social changes. This period is filled with emotional instability, external and internal conflicts, psychological and physical changes, in which there are risks for deviant behavior.

According to A. Samoilov and A. Tovkanets, in the modern processes of transformation of Ukrainian society, a field opens up for the formation of deviant attitudes among young people. Social and legal not maturity, lack of experience of moral behavior, along with complex processes in society contribute to the formation of various forms of deviant behavior (Samoilov, 2017; Tovkanets, 2012).

According to L. Kanishevska, adolescence is the most difficult of all periods of a child's development. This is especially true of younger adolescence, which is characterized by the so-called "peak of curiosity", and a tendency to risky behavioral reactions of the type: grouping with peers, emancipation, feelings of protest, testing of psychoactive substances (Kanishevska, 2017: 4). All processes, along with the features that are characteristic of adolescence, form negative behavioral attitudes in adolescents. From the peculiarities of adolescence M. Mykytenko distinguishes: 1) adolescent ambivalence; 2) lack of forecasting functions; 3) striving for self-knowledge and self-examination; 4) instability of self-esteem; 5) underestimation of self-esteem; 6) insufficient formation of the value-motivational sphere; 7) instability of the emotional-volitional sphere; 8) imitation of authority figures; 9) features of character accentuation (Mykytenko, 2019: 46).

According to a number of scientists (Tyulkevich, 2004; Zhukov, 2005; Novichkova, 2009; Gerasimova, 2009), adolescence is not only a very difficult period in the formation of a personality, but also the most favorable for the formation of moral, value-orientational and individual attitudes. The constant growth of deviant behavior in adolescence, the negative impact on society, requires the search for effective forms, methods and technologies to solve this problem. In the scientific literature, it is mainly proposed to carry out efforts aimed both at the rehabilitation of deviant children and at preventing deviations from social norms, that is, at eliminating negative conditions that directly or indirectly affect negatively the behavior of children and adolescents. Therefore, in science and in practice, the main technology for preventing the formation of deviant behavior among children is mainly preventive.

Prevention is a complex of efforts aimed at timely prevention and correction of negative information, pedagogical, psychological and organizational factors that influence the formation of negative social and personal development of children and youth (Kanishevska, 2017: 32). According to S. Śliwa, prevention is divided into: 1) Universal, which is focused on all students of a certain age category, regardless of the level of manifestation of problem behavior. Aimed at creating a supportive and welcoming atmosphere, positive impact on mental health and self-esteem, motivation to achieve success. 2) Selective, which focuses on high-risk groups. Aimed at group and individual preventive measures (pedagogical therapy, teaching social skills, sociotherapy). 3) Indicative, targeted at highrisk individuals. Individual work by specialists in external institutions (Śliwa, 2015: 15-16).

The most effective prevention, in our opinion, is prevention, which is designed to prevent deviant manifestations, appropriate education and the formation of attitudes that will help shape the personality, can withstand external and internal challenges. In addition, as stated in a number of works (Zhukov, 2005), the higher the age of the individual, the more difficult it is to influence his already formed attitudes. So, preventive activities should be started when there is a formation of volitional, motivational, value-orientational, moral, social attitudes, namely in 
early adolescence. Preventive activities need to be carried out for all children of this age category, because imitation is characteristic in this period, so this is best work in group actions. One of the means that can influence the formation of these structures is physical culture.

Physical culture in our time is known mainly as a discipline in the field of education in general education schools, which focuses on the practice of various physical and sports exercises, leads to the physical development of children based on motor skills or physical activity, thereby contributing to the education and development of young people. But physical culture has many positive aspects. B. Shyian believes that physical culture has a wide range of opportunities for moral education of adolescents. The upbringing of moral consciousness and behavior consists in addressing the spiritual essence of students (Shyian, 2000: 42-43). According to the WHO, regular physical activity during adolescence, in addition to developing motor skills, helps prevent and control feelings of anxiety and depression. Involvement in properly controlled physical activity and sports can promote the adoption of healthy behaviors, including quitting smoking, alcohol and drug use, and all kinds of violent behavior (World Health Organization, 2003: 3).

In general, physical activity has a positive effect on the development of children and adolescents, in addition to physical development, the effect is carried out on the psycho-emotional state - by improving memory, well-being teaches how to cope with fatigue and stress, has a positive effect on learning progress (assessments, behavior, concentration of attention), reduces the level of anxiety, reduces depression. Social status is also positively influenced - relations with others are formed, contributes to the creation of positive behavior within the framework of the idea of "fair play", teaches to win and lose, to learn cooperation, self-control, and can also be a good way to spend time with peers (Mazur at al., 2013: 11-12).

Modern scientists (Nechyporenko, 2016; Maslou, 1999; Ilin, 2000) increasingly associate people's behavior with their motivation. Motivation of human behavior can be based either on their internal motives and needs, or mainly on external impulses, the so-called stimuli. Needs and incentives are the main sources of human motivation. For adolescents, as well as for adults, according to A. Maslow, needs are the driving force behind motivation. In addition to the basic needs (physiological, safety), the following are also important: the need for self-realization (realization of one's own capabilities, in victory, in success) the need for respect and recognition (recognition of merit) social needs (the need for belonging, love, communication with people, existence of friends) (Maslou, 1999: 92-93). That is why needs are a powerful engine for taking action.

In childhood and adolescence, different needs begin to form. Thus, F. Talebzadeh asserts that physical culture and sports help adolescents to solve some of their needs: 1) in a healthy and strong body; 2) in activity and energy discharge; 3 ) in emotional balance; 4) in solving personal and family problems; 5) in the assimilation of the principles and rules of social life; 6) the need to understand personal values; 7) in the need to receive respect and gratitude; 8) in identifying external and internal talents (Talebzadeh, 2012: 1613). Therefore, when educating a person, you need to help in realizing their needs, help in the formation of adequate motivational attitudes.

In general, scientists argue that physical culture can influence the formation of personal skills that affect the behavior of children and adolescents. D. Nechyporenko determines that the set of certain motives that shape human behavior (Nechyporenko, 2016: 12). L. Nechyporenko claims that the motivational and emotional attitude to the process of physical education has a positive effect on behavior, both during classes and outside them (Nechyporenko, 2009: 92). Promoting motivation, according to these authors, should help in the formation of correct motivational attitudes towards positive behavior. 
Along with the motivational structure in the process of physical education, it is possible to influence the volitional categories of the personality. I. Dudnyk argues that volitional processes form the ability to act and act on the basis of conscious motives (Dudnyk at al., 2014: 4). A. Artyushenko determines that with the help of volitional regulation, conscious regulation of behavior and activity is carried out (Artiushenko, 2011: 5-6). With the help of volitional processes and volitional regulation, there is a conscious control of one's behavior in order to achieve one's own motives, which means that resistance to the manifestation of deviant behavior may arise.

I. Taranenko argues that adequate acceptance of social value orientations leads to variability in the nature of the norms and rules of the individual's behavior (Taranenko, 2017: 10-11). When forming positive value orientations, a socially acceptable choice of needs and goals occurs, and on the basis of motives and volitional efforts, they are realized. These qualities help to control their own behavior and the consequences of their own behavior. Adolescents who have a sufficient level of their own self-control, have the skills, the ability to observe control over their own behavior, have significant resistance to environmental influences.

Therefore, it can be argued that during the formation of volitional qualities, positive motivations, moral and volitional categories and value orientations in the process of physical education, the character of a person is formed, which is able to withstand the influences of the external and internal environment, as well as to control his actions and behavior. Therefore, an increase in personal development in children and adolescents contributes to the development of resistance to the negative influences of the external and internal environment.

In general, physical culture and sports are an important component in the upbringing of adolescents, in the formation of their social norms and attitudes, the acquisition of knowledge about a healthy lifestyle, as well as in the upbringing and prevention of deviant behavior. The preventive approach by means of physical culture is to create special conditions in which moral-volitional and social qualities, positive motivational attitudes and corresponding value orientations will be formed, which will allow to form a strong personality, surrendered to resist external and internal factors of the environment, and be a means of preventing deviant behavior.

\section{Determination of components, criteria and indicators of deviant behavior}

In order to determine the tendency to deviant behavior, we need to determine the structure of normative behavior, according to the levels of which we can determine socially acceptable behavior and deviant behavior in adolescents in the process of physical education. Analysis of the literature on deviant behavior shows that deviant behavior is an interdisciplinary component of behavior, indicating its personality manifestations. It can manifest itself in one social environment, but not in another. Therefore, the definition should cover general diagnostics, which should take into account both activities in the process of physical education and beyond.

According to the analysis of literary sources (Samoilov, 2017; Dudnyk, 2014; Nechyporenko, 2016; Petrovska, 2011), the general structure of the implementation of behavior is: a cognitive component (knowledge, understanding and awareness), an emotional-value component (emotions, motivation, value orientation), activity-behavioral (activity, activity, behavior). In addition, this content structure represents the interconnection of components with each other and their logical sequence, which can be depicted in the formula "I understand $\rightarrow$ I want $\rightarrow$ Action". The very general structure of normative behavior is shown in Fig. 1 .

Without a full level of knowledge, insufficient understanding of the features of normative behavior and awareness of the importance of the manifestation of this behavior, there is a 


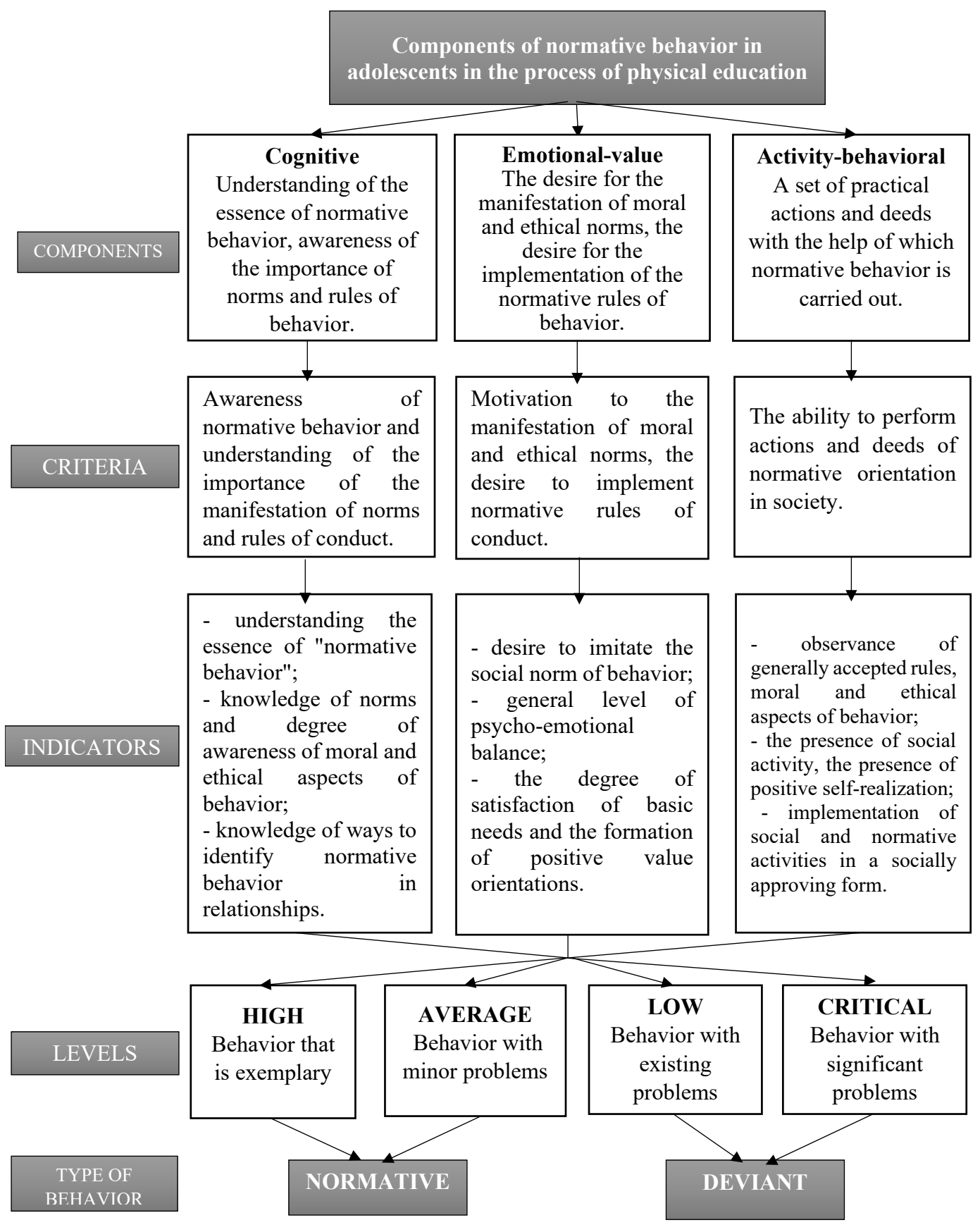

Fig. 1. General structure of normative behavior in adolescents in the process of physical education 
negative emotional reinforcement, the establishment of negative motivations to meet personal needs, an installation on negative value orientations and further manifestation of actions and deeds that are deviant.

According to a certain structure of normative behavior, it is possible to carry out diagnostics and, accordingly, this structure of criteria and indicators, it is possible to determine the dynamics of the effectiveness of prevention of deviant behavior in adolescents by means of physical culture.

The cognitive component was manifested in the system of knowledge of the essence of normative behavior, awareness of the importance of norms and rules of behavior. As a criterion for this component, we determined awareness of normative behavior, and the importance of manifestation of norms and rules of behavior. We have chosen as indicators: understanding of the essence of normative behavior; knowledge of norms and the degree of awareness of the moral and ethical aspects of behavior; knowledge about ways to identify normative behavior in relationships.

The emotional-value component reflects the desire to manifest moral and ethical norms, the desire to implement the normative rules of behavior. The criterion of this component is determined by the motivation for the manifestation of moral and ethical norms, the desire to implement the normative rules of behavior. We have chosen as indicators: the desire to imitate the social norm of behavior; general level of psycho-emotional balance; satisfaction of basic needs and the formation of positive value orientations.

The activity-behavioral component reflects the totality of practical actions and deeds with the help of which normative behavior is carried out. The criterion for this component is determined by the ability to manifest actions and deeds of a normative orientation in society. We have chosen as indicators: observance of generally accepted rules; moral and ethical aspects of behavior; the presence of social activity; the presence of positive self-realization; implementation of social and normative activities in a socially approving form.

Based on these indicators, four levels of normative behavior are determined: high, medium, low and critical. Based on the levels, the type of behavior is determined: acceptable, deviant.

Thus, the general structure we have defined is a methodology for diagnosing the level of formation of normative behavior in adolescents, for preventive activities by means of physical culture.

\section{Conclusions}

1. A generalizing analysis of scientific sources has shown that physical culture has effective means for the prevention of deviant behavior in adolescence. The most effective prevention is primary prevention, which is carried out within the framework of prevention, effective education and upbringing of individual, moral and social qualities, not only realizes and adheres to socially acceptable behavior, but also resists external and internal factors that contribute to the formation of deviant behavior.

2. According to the theoretical analysis of the literature on the topic of human behavior, it is possible to single out the general structure of normative behavior, which will determine the socially acceptable and deviant behavior. We have identified a number of the following components: cognitive, emotional-value and activity-behavioral. Each of these components has its own criteria and indicators, as well as levels that determine the type of behavior.

In the future, preventive activities can be carried out with the help of specially designed pedagogical conditions by means of physical culture. 


\section{References}

Artiushenko, A.O. (2011). Formuvannia v uchniv zahalnoosvitnoi shkoly osobystisnoi mobilnosti u protsesi fizychnoho vykhovannia [Formation of personal mobility in the process of physical education in students of secondary school]. Cherkasy. 394 p. [in Ukrainian]

Dubinin, S.N. (2016). Psihologicheskie osobennosti temperamenta nesovershennoletnih pravonarushitelej i mehanizmy korrekcii deviantnogo povedeniya lichnosti [Psychological characteristics of the temperament of juvenile offenders and the mechanisms of correction of deviant personality behavior]. Kostanay. 494 p. [in Russian]

Dudnyk, I.O., Artiushenko A.O. (2014). Vykhovannia voli v pidlitkiv u protsesi zaniat fizychnoiu kulturoiu [Education of will at teenagers in the course of employment by physical culture]. Cherkasy. 234 p. [in Ukrainian]

Gerasimova, I.G. (2009). Formirovanie fizicheskogo i psihicheskogo zdorovya podrostkov s deviantnym povedeniem na osnove spartianskih igr: $v$ usloviyah socialno-reabilitacionnogo centra [Formation of physical and mental health of adolescents with deviant behavior based on Spartan games: in a social rehabilitation center] (PhD Thesis). Naberezhnye Chelny. 184 p. [in Russian]

Ilin E. P. (2000) Motivaciya i motivy [Motivation and motives]. Saint Petersburg. 508 p.

Kanishevska, L. V. (2017). Teoretyko-metodychni aspekty profilaktyky shkidlyvykh zvychok $v$ uchniv 5-6 klasiv shkil-internativ [Theoretical and methodological aspects of prevention of bad habits in students of 5-6 grades of boarding schools]. Kyiv: Komprynt. 401 p. [in Ukrainian]

Maksimihina, E. V. (2006) Vliyanie differencirovannogo podhoda na zanyatiyah po fizicheskoj kulture i sportu na korrekciyu psihofizicheskogo sostoyaniya detej s deviantnym povedeniem [The influence of a differentiated approach in physical culture and sports lessons on the correction of the psychophysical state of children with deviant behavior] (PhD Thesis). Yaroslavl. 173 p. [in Russian]

Martyniuk, V. O. (2019). Systema psykholohichnoho suprovodu sotsialnoi readaptatsii nepovnolitnikh $v$ umovakh simeinoi depryvatsii [System of psychological support of social readaptation of minors in the conditions of family deprivation] (PhD Thesis). Sievierodonetsk. $362 \mathrm{p}$. [in Ukrainian]

Maslou, A. G. (1999) Motivaciya i lichnost [Motivation and personality]. Saint Petersburg: Evraziya. 478 p. [in Russian]

Mazur J., Oblacińska A., Jodkowska M., Małkowska-Szkutnik A., Tabak I., Zawadzka D., Dzielska A., Stalmach M., Radiukiewicz K. (2013), Aktywność Fizyczna Młodzieży Szkolnej w wieku 9-17 lat: aktualne wskaźniki, tendencje ich zmian oraz wybrane zewnętrzne $i$ wewnętrzne uwarunkowania [Physical Activity of School Youth aged 9-17: current indicators, trends in their changes and selected external and internal conditions]. Warszawa. 222 p. [in Polish]

Minnegaliev M. M. (2004) Fizkulturno-ozdorovitelnaya deyatelnost v shkole kak sredstvo profilaktiki deviantnogo povedeniya nesovershennoletnij [Physical culture and health-improving activity at school as a means of preventing deviant behavior minor] (PhD Thesis). Ufa. 205 p. [in Russian]

Monzonis Martínez, N. (2015). La Educación Física como elemento de mejora de la competencia social y ciudadana [Physical Education as an element to improve social and civic competence] (PhD Thesis). Barcelona. 1102 p. [in Spanish]

Nechyporenko, D. L. (2016). Formuvannia u pidlitkiv motyvu dosiahnennia uspikhu u protsesi fizychnoho vykhovannia $v$ zahalnoosvitnikh navchalnykh zakladakh [Formation in adolescents 
of the motive of success in the process of physical education in secondary schools] (PhD Thesis). Kyiv. 205 p. [in Ukrainian]

Nechyporenko, L.A. (2009). Pedahohichni umovy zabezpechennia osobystisnykh dosiahnen pidlitkiv zasobamy fizychnoi kultury [Pedagogical conditions for ensuring the personal achievements of adolescents by means of physical culture] (PhD Thesis). Cherkasy. 225 p. [in Ukrainian]

Novichkova, N.G. (2009). Pedagogicheskaya korrekciya deviantnogo povedeniya podrostkov sredstvami fizicheskoj kultury [Pedagogical correction of deviant behavior of adolescents by means of physical culture] (PhD Thesis). Chelyabinsk. 184 p. [in Russian]

Petrovska, K.V. (2011) Diahnostyka rivnia sformovanosti suspilno-normatyvnoi povedinky uchnivskoi molodi tvorchykh neformalnykh obiednan [Diagnosis of the level of formation of social and normative behavior of student youth of creative informal associations]. Donetsk: Landon$X X I .123$ p. [in Ukrainian]

Revenko, S. P. (2020). Sotsialno-psykholohichni umovy stanovlennia zriloi identychnosti studentskoi molodi [Socio-psychological conditions for the formation of a mature identity of student youth] (PhD Thesis). Sievierodonetsk. 286 p. [in Ukrainian]

Samoilov, A. M. (2017). Profilaktyka deviantnoi povedinky pidlitkiv u sotsialnovykhovnomu seredovyshchi zahalnoosvitnoi shkoly [Prevention of deviant behavior of adolescents in the socio-educational environment of secondary school] (PhD Thesis). Vinnytsia. $282 \mathrm{p}$. [in Ukrainian]

Shyian, B. M. (2008) Teoriia i metodyka fizychnoho vykhovannia shkoliariv. Chastyna I [Theory and methods of physical education of schoolchildren. Part I]. Ternopil: Navchalna knyhaBohdan. 272 p. [in Ukrainian]

Shyian, B. M. (2000). Teoriia fizychnoho vykhovannia [Theory of physical education]. Ternopil: Zbruch. 183 p.

Śliwa, S. (2015) Szkolne programy profilaktyki a edukacja wczesnoszkolna [School prevention programs and early school education]. Warszawa. 106 p. [in Polish]

Talebzadeh, F., Jafari, P. (2012). How Sport and Art could be Effective in the Fields of Social, Cognitive and Emotional Learning? Procedia - Social and Behavioral Sciences, Volume 47, 1610-1615. DOI: http://10.1016/j.sbspro.2012.06.871_[in English]

Taranenko, I. V. (2017). Osobystisno oriientovanyi pidkhid do vykhovannia vazhkykh pidlitkiv u protsesi zaniat fizychnoiu kulturoiu [Personality-oriented approach to the education of difficult adolescents in the process of physical education] (PhD Thesis). Uman. 262 p. [in Ukrainian] Tovkanets, O. S. (2012). Pedahohichni umovy profilaktyky deviantnoi povedinky uchniv profesiino-tekhnichnykh uchylyshch [Pedagogical conditions for the prevention of deviant behavior of students of vocational schools] (PhD Thesis). Ternopil. 325 p. [in Ukrainian]

Tyulkevich, V.G. (2004). Fizkulturno-sportivnaya deyatelnost prikladnoj napravlennosti v reshenii zadach socialnoj adaptacii podrostkov s deviantnym povedeniem [Physical culture and sports activity of applied orientation in solving problems of social adaptation of adolescents with deviant behavior] (PhD Thesis). Khabarovsk. 153 p. [in Russian]

World Health Organization (2003). Health and Development Through Physical Activity and Sport. Geneva. [in English] Retrieved from: http://www.who.int/whr/2003/en/index.html (accessed 21 april, 2021)

Zhukov, M.N. (2005). Socialno-pedagogicheskie i ozdorovitelnye tehnologii v fizicheskom vospitanii detej i podrostkov s deviantnym povedeniem [Socio-pedagogical and health-improving technologies in the physical education of children and adolescents with deviant behavior] (PhD Thesis). Moscow. 370 p. [in Russian] 